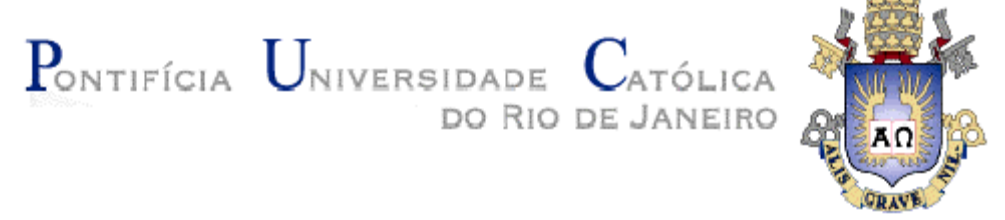

Lúcia Helena Gazólis de Oliveira

Livro Didático e aprendizado de leitura no início do ensino fundamental

Dissertação de Mestrado

Dissertação apresentada como requisito parcial para obtenção do grau de Mestre pelo Programa de Pós-Graduação em Educação do Departamento de Educação da PUC-Rio.

Orientador: Prof. Creso Franco 


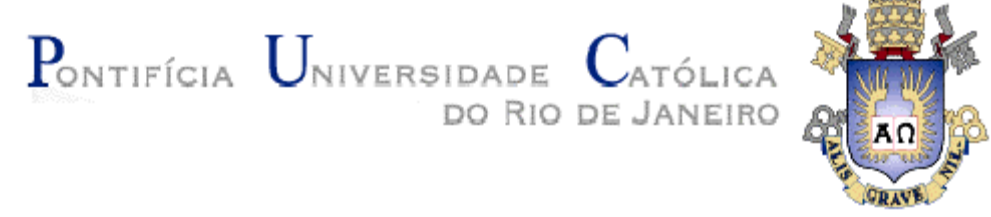

Lúcia Helena Gazólis de Oliveira

\section{Livro Didático e aprendizado de leitura no início do ensino fundamental}

Dissertação apresentada como requisito parcial para obtenção do grau de Mestre pelo Programa de Pós-Graduação em Educação do Departamento de Educação do Centro de Teologia e Ciências Humanas da PUC-Rio. Aprovada pela Comissão Examinadora abaixo assinada.

Prof. Creso Franco

Orientador

Departamento de Educação - PUC-Rio

Prof $^{\mathrm{a}}$ Maria Fernanda Rezende Nunes

Departamento de Educação - PUC-Rio

Prof $^{a}$ Ceris Salete Ribas da Silva

UFMG

Prof. Paulo Fernando C. de Andrade Coordenador Setorial do Centro de Teologia e Ciências Humanas

Rio de Janeiro, 11 de abril de 2007. 
Todos os direitos reservados. É proibida a reprodução total ou parcial do trabalho sem autorização da universidade, da autora e do orientador.

\section{Lúcia Helena Gazólis de Oliveira}

Lúcia Helena Gazólis de Oliveira graduou-se em Serviço Social pela Universidade Federal do Rio de Janeiro em 1998 e em Pedagogia pela Universidade do Estado do Rio de Janeiro em 1995. Em 2001, especializou-se na área de Violência Doméstica Contra Crianças e Adolescentes pela Universidade de São Paulo. Atua como professora do ensino fundamental desde 1986. Até 1998 desenvolveu atividades de ensino e de coordenação pedagógica em escolas municipais do Rio de Janeiro. Desde 1999 é professora do Colégio de Aplicação da UFRJ, onde também atua na orientação de licenciandos e na coordenação do projeto de pesquisa "Contexto-Ação: um estudo sobre a prática da produção de textos". Integra a pesquisa GERES: Estudo da Geração Escolar 2005 junto à PUC - Rio.

Ficha Catalográfica

Oliveira, Lúcia Helena Gazólis de

Livro didático e aprendizado de leitura no início do ensino fundamental / Lúcia Helena Gazólis de Oliveira ; orientador: Creso Franco. 2007.

132 f. : il. ; $30 \mathrm{~cm}$

Dissertação (Mestrado em Educação)Pontifícia Universidade Católica do Rio de Janeiro, Rio de Janeiro, 2007.

Inclui bibliografia

1. Educação - Teses. 2. Leitura. 3. Livro didático. 4. PNLD. 5. Estudo longitudinal. 6. Valor agregado. I. Franco, Creso. II. Pontifícia Universidade Católica do Rio de Janeiro. Departamento de Educação. III. Título. 
À minha família, alicerce de todas as minhas conquistas. À Albaney Baylão, companheiro que incentiva e apóia meu crescimento. Aos professores que me ensinaram a acreditar.Aos meus alunos, com os quais sempre aprendo. 


\section{Agradecimentos}

Aos idealizadores e implementadores do Projeto GERES: por viabilizarem os dados da pesquisa e por seu compromisso e determinação em apontar novos caminhos para a Educação.

Aos professores do Departamento de Educação, em especial ao professor Creso Franco, por me ensinar a usar novas ferramentas para olhar a Educação, por acreditar no meu potencial e me incluir em espaços acadêmicos.

À professora Ceris Ribas, pelos dados referentes às avaliações dos livros didáticos e à professora Lea Gaudenzi pelos Guias do Livro Didático.

À PUC-Rio pela gratuidade do curso, à UFRJ pela licença para estudos e aos colegas do CAp pela compreensão e apoio. 


\section{Resumo}

OLIVEIRA, Lúcia Helena Gazólis de; Franco, Creso. Livro Didático e aprendizado de leitura no início do ensino fundamental. Rio de Janeiro, 2007, 132 p. Dissertação de Mestrado - Departamento de Educação, Pontifícia Universidade Católica do Rio de Janeiro.

O estudo se insere no âmbito das investigações sobre escolas eficazes. Utiliza dados de survey longitudinal, obtidos pela pesquisa GERES: Estudo da Geração Escolar 2005. A subamostra corresponde a 3.454 alunos da primeira série do Ensino Fundamental (ou seu equivalente em ciclo), e seus respectivos professores, distribuídos em 176 turmas, de 68 escolas pertencentes às redes municipal, privada e federal do Rio de Janeiro. Transitando-se entre as vertentes qualitativa e quantitativa, procurou-se medir, descrever e interpretar o valor agregado pelos professores às suas turmas, em leitura, especialmente no que diz respeito ao uso do livro didático de Língua Portuguesa. Aprofunda-se o tema, articulando-se as concepções de alfabetização no Brasil nas últimas décadas com as características do Programa Nacional do Livro Didático (PNLD) e com as formas de apropriação por parte dos professores em relação a essa política. A literatura referente à eficácia escolar e o aprofundamento do tema específico fundamentam as análises dos dados e conseqüentes conclusões. Na vertente qualitativa, foi construída uma escala de proficiência que, interpretada, resulta na descrição de sete níveis de aprendizagem, o que confere sentido pedagógico à escala. São apresentados os resultados alcançados pelos estudantes em leitura, tendo-se em consideração as particularidades das dependências administrativas às quais estão vinculados. Mostra-se como ocorreu a mobilidade de alunos entre os níveis de aprendizagem em função da utilização ou não do livro didático. Na vertente quantitativa, são implementados modelos de regressão linear que investigam o efeito do uso do livro didático, do tempo de experiência do professor com o referido livro e da menção recebida pelo livro no PNLD. Os resultados evidenciam um aumento significativo do aprendizado médio apresentado pelos alunos participantes do estudo, o que contradiz hipótese recorrente no meio educacional, segundo a qual o fracasso 
identificado nas séries iniciais do Ensino Fundamental teria origem no processo de alfabetização. Destacam-se, entre os achados, maior 'valor agregado' pelos alunos que utilizaram livro didático e benefícios ainda maiores para estudantes cujos professores tinham mais de dois anos de experiência com o uso do mesmo livro. Em termos de política pública, a dissertação sugere que a avaliação de livros didáticos - e, em sentido mais geral, de programas educacionais - considere também o efeito sobre o aprendizado.

\section{Palavras-chave:}

Leitura, livro didático, PNLD, estudo longitudinal, valor agregado. 


\section{Abstract}

Oliveira, Lúcia Helena Gazólis de; Franco, Creso (Advisor). Textbook and reading learning process in the beginning of primary education. Rio de Janeiro, 2007, 132 p. MSc. Dissertation - Departamento de Educação, Pontifícia Universidade Católica do Rio de Janeiro.

This research is included in the investigation about efficaciousness schools. It uses longitudinal survey data from the GERES Project: School Generation Research 2005. The part of the sub-sample studied corresponds to 3454 students from the first year of the primary education (or its equivalent) and its respective teachers of 176 classes, from 68 private, municipal or federal schools in Rio de Janeiro. Moving through quantitative and qualitative approaches, the added value in reading by the teachers to the classes is measured, described and interpreted, specially related to the use of Portuguese textbooks. Through in depth study of this theme, the conceptions about Brazil alphabetization that have appeared in previous decades and have considered the characteristics of the Textbooks National Program (PNLD) and the appropriation of these politics by the teachers are articulated. The literacy referred to the scholar efficaciousness and the research into this specific theme are the basis for the data analysis and its conclusions. In the qualitative approach a proficiency scale was built and, when it is interpreted, results in a description of seven learning levels, proving its inherent significance of the scale to teaching. The reading results reached by the students are presented, considering the administrative dependences that they are linked to. The students mobility is presented within the learning levels according to whether they used or didn't use textbooks. In the quantitative approach, a linear regression model was implanted, which investigated the effect of the use of textbooks, how much experience the teacher had with that book and what PNLD says about the same book. The study verified that there was a significant increase in the learning average of the students that participated in the research. This contradicted a recurrent hipothesis in the educational area that suggested that the failure in the beginning levels of the primary education has origin in the alphabetization 
process. Among the results, stands out that there was more added value by the students that used the textbook and much more benefits to the students whose teachers had more than two years experience with the same book. In terms of public politics, this dissertation suggests that the textbook evaluation - and, in a more general form, the educational programs - considers the effect on the learning too.

\section{Key-words:}

Reading, textbook, PNLD, longitudinal study, added value. 


\section{Sumário}

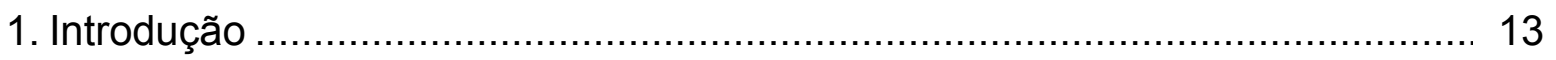

2. Os estudos sobre escolas eficazes ………............................................ 17

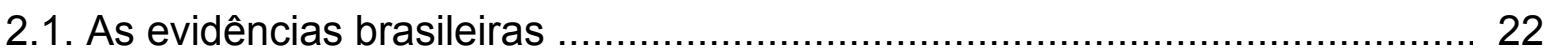

2.2. Estudo Longitudinal da Geração Escolar 2005 (GERES): definição e

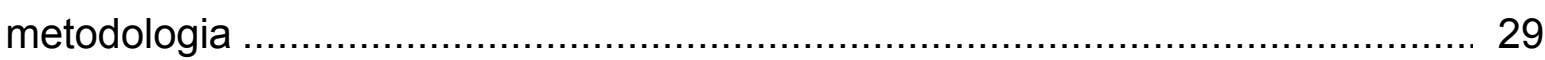

3. As concepções de alfabetização no Brasil nas últimas décadas .................... 34

4. O Programa Nacional do Livro Didático .................................................... 45

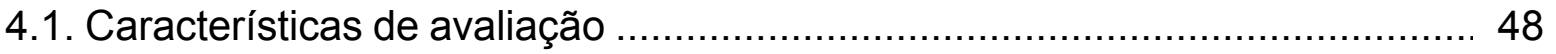

4.2. Impactos, apropriação docente e perspectivas: o que mostram as pesquisas decorrentes do PNLD ........................................................... 54

5. Instrumentos de coleta de dados e amostra ...........................................6 66

6. A vertente qualitativa da pesquisa ..................................................... 73

6.1. Concepção de leitura na pesquisa GERES: a matriz de referência ............ 74

6.2. A escala de proficiência em leitura ..................................................... 79

6.3. A interpretação pedagógica as escala .................................................. 81

6.4. Resultados: o que e quanto aprenderam os alunos durante a primeira

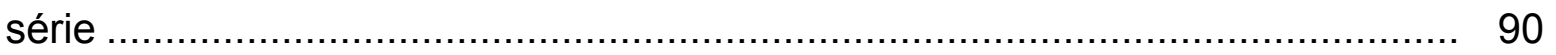

6.4.1. Um estudo comparativo entre alunos que utilizaram e que não utilizaram livro didático .......................................................................... 99

7. A vertente quantitativa da pesquisa ..................................................... 103

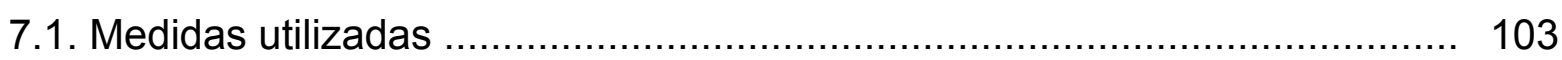

7.2. Abordagens de análise ............................................................. 104

7.3. Resultados: o efeito do uso do livro didático na proficiência dos alunos ..... 106

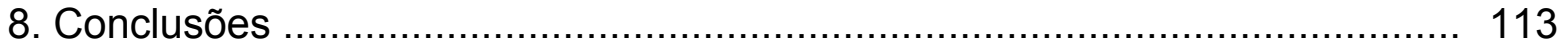

9. Referências bibliográficas ............................................................... 120

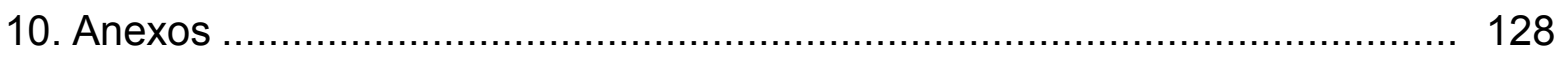




\section{Lista de Figuras}

Figura 1 - Curva característica de um item com os principais pontos do desenvolvimento de habilidades

Figura 2 - Distribuição das escolhas dos docentes no PNLD/2004 ................... 70

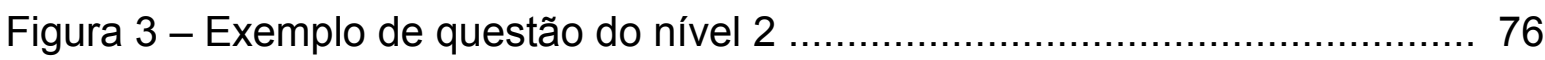

Figura 4 - Exemplo de questão do nível 3 .......................................... 76

Figura 5 - Exemplo de questão do nível 4 ................................................ 77

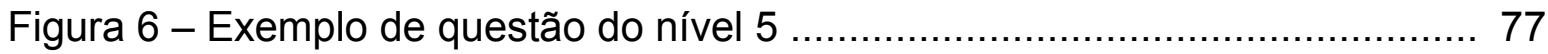

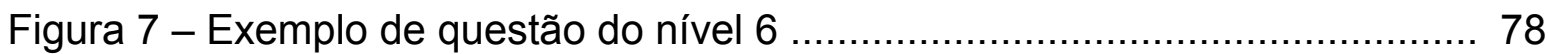

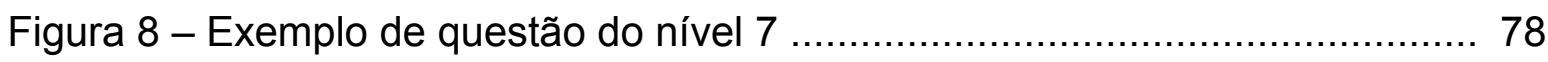

Figura 9 - Curva representativa do aprendizado dos estudantes dos

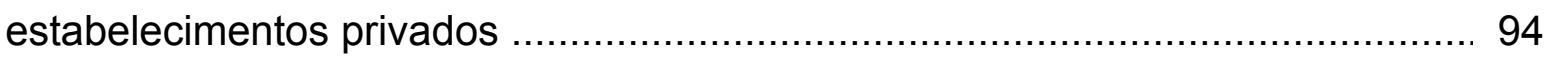

Figura 10 - Curva representativa do aprendizado dos estudantes dos

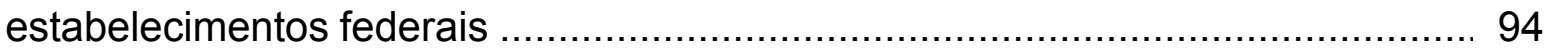

Figura 11 - Curva representativa do aprendizado dos estudantes dos estabelecimentos municipais

Figura 12 - Gráfico de dispersão (distribuição das turmas em relação ao ajuste do modelo)

\section{Lista de Tabelas}

Tabela 1 - Percentual de alunos por nível de aprendizagem nas ondas 1 e 2 para o total da amostra

Tabela 2 - Percentual de alunos por nível de aprendizagem nas ondas 1 e 2 por dependência administrativa

Tabela 3 - Percentual de alunos por nível de aprendizagem em função da utilização ou não de livro didático 99

Tabela 4 - Mobilidade dos alunos entre os níveis em função da utilização ou não do livro didático 100

Tabela 5 - Estatística descritiva das variáveis utilizadas 104

Tabela 6 - Resultado dos modelos estimados para as redes municipal, federal e privada 106

Tabela 7 - Resultado dos modelos estimados para a rede municipal 110 


\section{Lista de Quadros}

Quadro 1 - Livros de Língua Portuguesa utilizados pelos professores/alunos pesquisados não avaliados no PNLD/2004

Quadro 2 - Livros de Língua Portuguesa utilizados pelos professores/alunos pesquisados avaliados no PNLD/2004 69

Quadro 3 - Distribuição da amostra por dependência administrativa (em\%) ..... 71

Quadro 4 - Escala de proficiência em leitura .............................................. 80

Quadro 5 - Descrição dos níveis de aprendizagem em leitura ......................... 89

Quadro 6 - Descrição das variáveis utilizadas ............................................. 103 